\title{
LAUREN BLISS \\ The Cinematic Body in View of the Antipodes: Philip Brophy's Body Melt as the bad copy
}

\begin{abstract}
Through a wide ranging study of Philip Brophy's academic and critical writings on horror cinema, this essay considers how Brophy's theory of the spectator's body is figured in his only horror feature Body Melt (1993). Body Melt is noteworthy insofar as it poorly copies a number of infamous sequences from classical horror films of the 1970s and 1980s, a form of figuration that this essay will theorise as distinctly Antipodean. Body Melt will be related as an antagonistic 'turning inside out' of the subjectivity of the horror movie spectator, which will be read in the light of both the usurped subject of semiotic film theory, and the political aesthetics of Australian exploitation cinema.
\end{abstract}

Philip Brophy's Body Melt, made in 1993, is a distinctly antipodean film: it not only copies scenes from classic horror movies such as The Hills Have Eyes (1977), Alien (1979), The Thing (1982) and Scanners (1981), it also copies the scenes badly. Such copying plays on and illuminates the 'rules' of horror as the toying with and preying upon the spectator's expectation of fear. Brophy's own theory of horror, written across a series of essays in academic and critical contexts between the 1980s and the 1990s, considers the peculiarity of the spectator's body in the wake of the horror film. It relates that the seemingly autonomic or involuntary response of fear or suspense that horror movies induce in a viewer is troubled by the fact that both film and viewer knowingly intend this response to occur from the very beginning. His writing harnesses this fact to theorise the epistemological, moral, and political consequences of such a body. This essay will consider how his only feature Body Melt figures his theory in relation to the rules of horror on the terms of an inversion, which operates not simply through the bad copying but also between sound and image, and body and screen, illuminating the paradoxical subjectivity of the horror film spectator.

Here, a full discussion of the epistemological and theoretical implications of Body Melt and Brophy's theory of horror will be grounded in the figure of the Antipodean. In reference to Australian culture, the 'antipodal' has been understood as the 'art of the copy', and its visual invention as necessarily imitative. This figure of the antipodean was applied by Australian art theorists and critics in the 1980s as a metaphor for the imitative condition of Australian art and cinema. In its condition of always pointing to an 'elsewhere', Antipodean theory is not necessarily a reference to Australian art and cinema as 'second-rate', in the sense of a category of taste or value. Rather, it represents the beginnings of a theory of Australian art and film. ${ }^{3}$ This essay will read the reproductive dimension of Body Melt through the theory of the antipodean copy. The antipodean, as an imitative turning 'inside-out', will be used to argue that the artistic achievement of Body Melt is a form of figuration aimed at antagonising the bodily subjectivity of the horror movie spectator. Such antagonism will be further traced

\footnotetext{
${ }^{1}$ Butler, 2004.

${ }^{2}$ Smith, 1974, see also Cholodenko, 2010 for discussion of the B-movie in relation to Baudrillard's approach to the Platonic simulacrum.

${ }^{3}$ Frow and Morris, 1993.
} 
through a wide-ranging discussion of Brophy's writing on film, and positioned in the light of semiotic film theory, and the political and aesthetic dimension of Australian exploitation cinema.

To introduce Brophy's theory of the horror film, he places a paradoxical split between the spectator's mind and body. As he emphasises in his essay 'Horrality' — originally published in Art \& Text in 1983, and republished in Screen in 1986 - such films are marked by the 'game' that the spectator 'plays with the text':

The contemporary Horror film knows that you've seen it before; it knows that you know what is about to happen; and it knows that you know it knows you know. And none of it means a thing, as the cheapest trick in the book will still tense your muscles, quicken your heart and jangle your nerves. ${ }^{4}$

In an earlier essay 'Tales of Terror', published in Cinema Papers in 1984, Brophy contends that this irrational encounter is premised on bodily response: '[T]hey [horror movies] manipulate the nervous system more than the brain, fuel anxieties more than emotions, evoke fears more than opinions, ravage bodies more than imaginations. One might call this an abuse of the cinema. I simply call it the cinema. ${ }^{5} \mathrm{He}$ emphasises that this is part and parcel of the textuality of the horror film as geared toward a visceral rather than cerebral response. As 'a mode of fiction, a type of writing that in the fullest sense 'plays' with its reader' the gratifying effect is precisely to build 'tension, fear, anxiety [...] a disposition that is overall both tasteless and morbid'. ${ }^{6}$ For Brophy, the classic horror films of the 1970s and 1980s confer an inverted chain of cause and effect, where the desire to both look at and look away from what is on screen is secondary to the primary elicitation of bodily affect.

Brophy relates that horror films figure this paradoxical contradiction from within the body of the viewer. While one is aware that what they are watching is indeed 'only a movie' it nonetheless works 'with immediate results'. The body, in this light, can be positioned as the cause that also produces its own (nonetheless irrational) effect. In the words of Brophy: 'The contemporary Horror film tends to play not so much on the broad fear of Death, but more precisely on the fear of one's own body, of how one controls and relates to it. ${ }^{8}$ Brophy is particularly responding to horror and science fiction films of the 1970s and 1980s, including classics such as The Texas Chainsaw Massacre, Alien, The Brood, The Hills Have Eyes, and Dawn of the Dead. He is interested in how the spectator of these films deliberately seeks out horror and acts as 'a willing target that both constructs the terror and is terrorised by its construction'; ${ }^{9}$ and he considers how the films encourage an identification that is 'levelled at that loss of control - the fictional body is as helpless as the viewing subject. ${ }^{10}$

\footnotetext{
${ }^{4}$ Brophy, 1986, p. 5.

${ }^{5}$ Brophy, 1984, p. 407.

${ }^{6}$ Brophy, 1986, p. 5.

${ }^{7}$ Brophy, 1986, p. 11.

${ }^{8}$ Brophy, 1986, p. 8.

${ }^{9}$ Brophy, 1986, p. 5.

${ }^{10}$ Brophy, 1986, 1986, p. 10.
} 
I argue that his only feature film Body Melt takes up this paradoxical body as its subject through its bad reproduction of key sequences from classic horror films of the 1970s and 1980s. Here, the antipodean can be deployed to figure and to 'flesh-out' the significance of the copying that occurs in Body Melt and how it targets the body of the willing spectator. As it badly reproduces key sequences from classic horror films, so does it confer an antipodean figuration of the horror viewer's bodily subjectivity. In Brophy's formulation this body is paradoxically the agent of its own horrified response, a reflexivity produced by horror scenarios constructed in the manner of 'knowing that you know it knows you know'. The effect of the deliberately bad reproduction of such classic sequences in Body Melt is an antipodean draining or evacuation of filmic significance to illuminate, through an antagonising 'badness', how the subject of the horror film causes the body to affect horror or terrified response unto itself.

The implications of this will be later related to Brophy's attack on semiotic film theory of the 1970s and 1980s, and to his reading of the political value of exploitation cinema (a genre to which Body Melt belongs). To relate antipodean figuration to Body Melt, we must first attend to the reproductive motifs and elements present within the film. Body Melt is the story of a group of ordinary suburbanites from Pebbles Court, Holmesville - themselves played by a variety of house-hold name B-grade and C-grade Australian soap stars and television personalities including Lisa McCune and William McInnes (of Blue Heelers); Ian Smith (Neighbours); Brett Climo (Sons and Daughters, A Country Practice) and Andrew Daddo (Round the Twist, World's Greatest Commercials). The residents are the unwitting victims of a local health laboratory, receiving directly targeted sample packs of vitamins in their letterbox from 'Vimuville' and unaware of their deadly, parasitic effects. The vitamins are advertised as the ultimate health boosters, but in fact cause the body to metastasise and attack itself. Spectacularly gory deaths ensue a day or so after the drinks are ingested. Passing through stages of 'Hallucination' and 'Organ Failure' to 'Body Melt', the drinks cause the flesh to liquefy and the victims are reduced to a catatonic stupor. Brophy, referring to the famous Australian soap, calls Body Melt an 'infected Neighbours' ${ }^{11}$ and indeed infection is another central motif. After the drink is consumed, the body extinguishes itself, and its parts indiscriminately explode - penises, uteruses, heads, eyeballs and tongues are overcome with an alien force, attacking their human host and any unwitting person who happens to be nearby.

In one significant sequence, a parody of the face-hugging scene in Alien, the pregnant Cheryl's foetus bursts out and asphyxiates her husband. In this sequence, Cheryl (McCune) anticipates that something is wrong with her baby. This worry is quickly turned comical when a placenta falls out of her and onto the floor. In a daze, she telephones her doctor (played by Smith, who is in on the experiment) to ask whether or not this is 'normal'. In a succession of shots, Cheryl blinks or hesitates and the placenta disappears. The audience, cued to the famous scene in Alien, will know that it has crawled away. Cheryl absurdly reenacts this knowledge, seeming to accept the impossibility that her placenta has disappeared. She desperately but deliberately hunts down the placenta amidst the mess of her new home,

\footnotetext{
${ }^{11}$ Brophy, 2006, p. 20.
} 
and the features of the suburban dwelling are exaggerated by the camera foregrounding ordinary household objects: for example, in this shot where the image of Cheryl, peering over the kitchen bench, is balanced by the bottle of Ajax Spray and Wipe and a dirty cleaning rag (Fig. 1). The music is a synthesised pop symphony that hinges its suspense on a moulding of idle elevator music with the pace of an aerobics workout. The bad reproduction in this sequence antagonises the knowing spectator's body and their expectation of horror, as it turns the 'game' of the horror movie on itself. (Fig. 2)

The antipodean elements of such a sequence, related through the figure of the pregnant Lisa McCune, can also be extended to consider how the pregnant, or reproductive, monster is a common trope in horror and science fiction films. In films such as Invasion of the Body Snatchers and John Carpenter's The Thing, the living human body is ensnared or entrapped in an inescapable inversion of the reproductive chain. In these films, the living-dead alien reproduces through the human, forming a visual parasite aimed at meaningless reproduction. Humans look the same as they did before, only now they are without emotion and their only intention is to reproduce same-for-same. The Thing is a film where neither protagonists nor the spectator know who the alien is. 'The Thing' is an extraterrestrial virus that infects hosts without changing their outer human appearance. The characters try to track down 'The Thing', but it cannot be seen. As in Invasion of the Body Snatchers, which figures a similar kind of reproductive body that takes away the possibility of visible distinction between the alien and the human, in The Thing the body imperceptibly dislocates, relocates, and metamorphoses within the perceptible form of the human body.

In Body Melt reproduction is also figured on the terms of the 'film within a film', itself a meta-commentary on the impossible topology of the inside/outside perspective between spectator and screen. This occurs at the level of bad copying and in the opening sequence, which begins as an infomercial for Vimuville Health Farm starring Shaan (Regina Gaigalas), the CEO of the company. Shaan walks around the farm, showing its state of the art facilities designed to help families miraculously revitalise their wellbeing. Cheesy music accompanies the montage; Shaan walks with the camera panning from right to left, and the film cuts between various locations, from the front of the building, the inside of an office, and a gymnasium. Spectators who are familiar with late-night television, in particular the home shopping channel, will recognise the aesthetics on screen; particularly as it appears to have been shot on a cheap video camera. The sequence that follows transitions to a naked, sweaty Shaan 'shooting up' vitamins with her monstrously muscular boyfriend, all filmed on crystal clear $35 \mathrm{~mm}$. The cold lighting, nudity and excessively sweaty bodies convey a sense of illness, unease and addiction that is nonetheless made comical by its hyper-exaggerated, erotic display. The transition between the two sequences, played off not simply as a 'film within a film', but also as the dichotomy of the sick/healthy body, can be further placed in the 


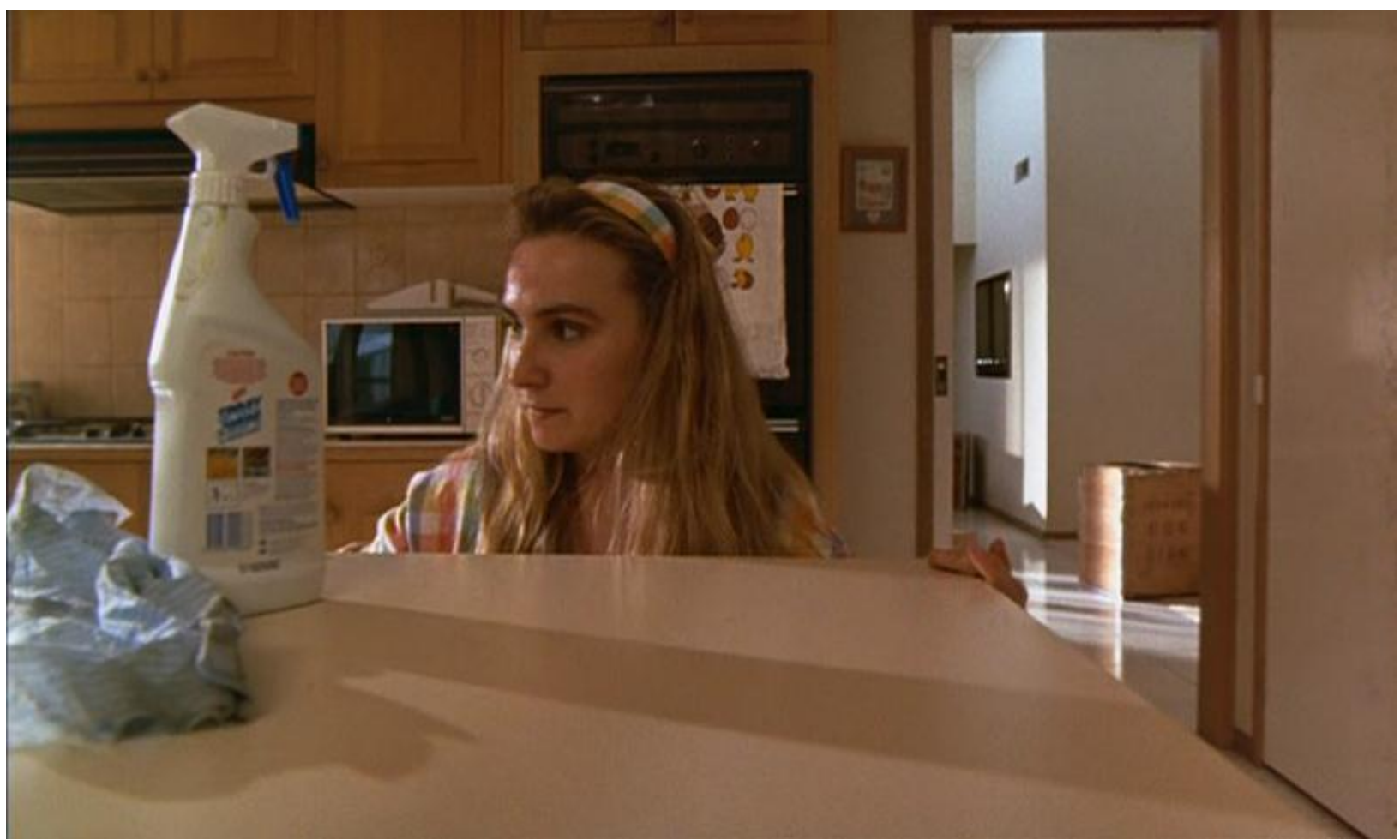

Fig. 1. Screenshot from Body Melt: Cheryl (Lisa McCune) hunting down her lost placenta. (Copyright: Philip Brophy.)

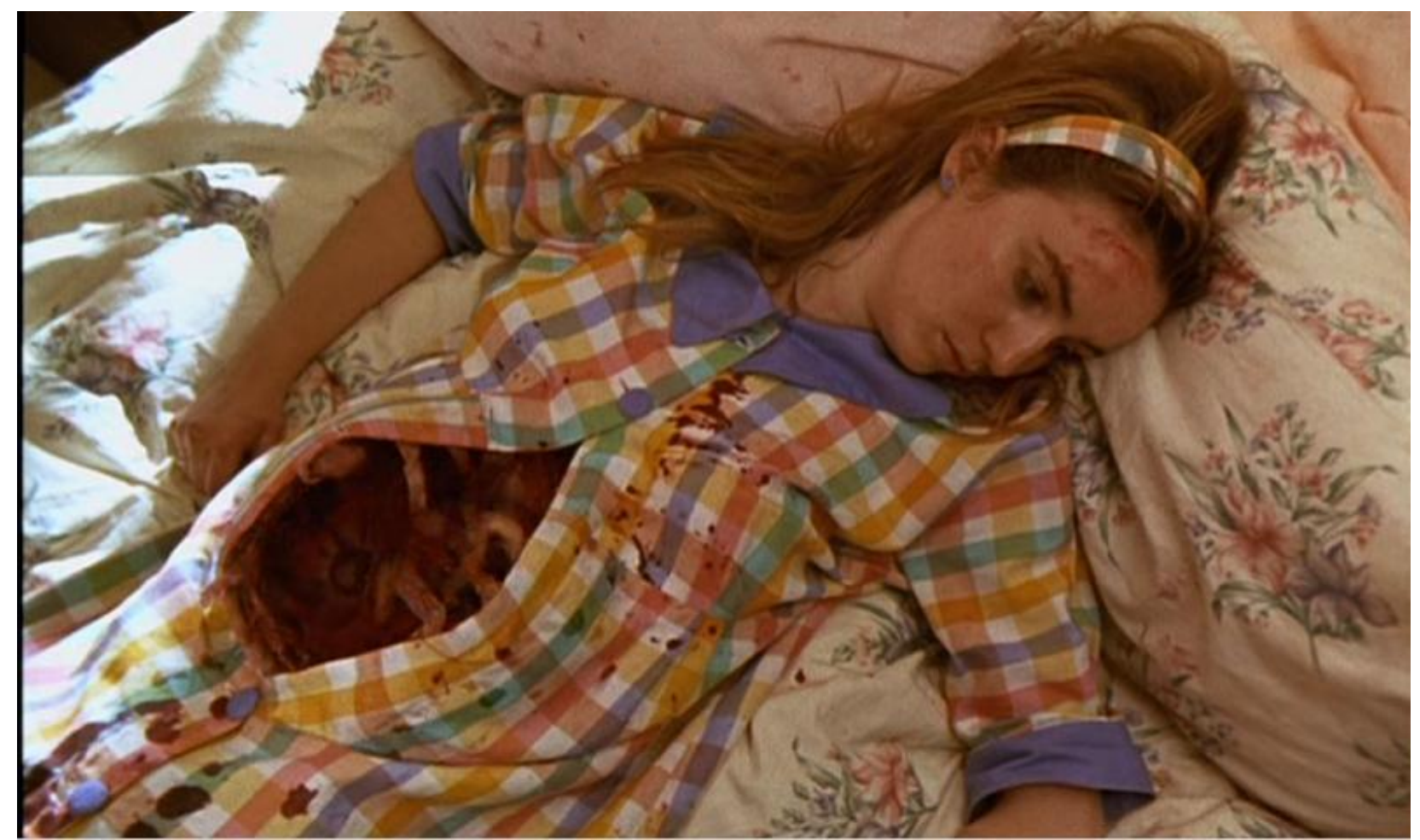

Fig. 2. Screenshot from Body Melt: Cheryl after the foetus has burst out from her uterus. (Copyright: Philip Brophy.) 
light of Brophy's 1987 essay, 'This isn't a film, it's a disease'. ${ }^{12}$ In it, he discusses the way that horror films have been labelled as sick or degenerate by censoring and governmental bodies. Critiquing empirical psychological studies that have argued horror films cause violent behaviour, which led to classification and ratings systems designed to protect children and adolescents, Brophy demands that horror films be recognised for the way that they knowingly play upon social conventions: "Many "sick" films play at being sick by deliberately provoking the wrath of conservatives and those ignorant of the conventions, or by plunging into that great chasm where only attuned sensibilities can illuminate the exact slant of the film. ${ }^{13}$

Without delving further into Brophy's polemical critique of the censorship of horror, we can approach and expand upon this notion of the body as it is figured in Body Melt. Attending to the paradoxical or irrational split between spectator and screen demands that the body be recognised from the point of view of the willed submission of the spectator to 'take into account how the individual exercises control', through what he calls 'mutual engagement ... a willingness to be played with and by a film. ${ }^{14}$ The antipodean is illuminating in this respect, as it simultaneously attends to the split between viewer and screen, and the reproductive elements within the film. It also provides for the 'Australianness' of the film; however, I will not address that until later in this essay.

While the antipodean is a figure of speech, noun or adjective, that connotes what is from the antipodes, or the southern hemisphere, especially Australia and New Zealand, the antipodes is also defined in geometrical terms as the point of diametrical opposition, and the antipodean is a person who walks with their feet above their head (as derived from the Greek antipous 'with feet opposite'). ${ }^{15}$ The term 'antipodean' has been applied in both sociology and arthistory as a means to read the typically Australian form of the cultural cringe, which is a recognition of the inferiority of one's culture and its products, usually measured against the standards of the United States or Europe. ${ }^{16}$

When used in an ironic fashion the cultural cringe typically issues in the application of perverse humour, the kind that is also evident in Body Melt. In his essay 'Australia: The Unhappy Country', a play on the idiomatic expression for Australia as the 'lucky country', 17 Peter Beilharz refers to the antipodes as the 'dregs' of the earth: 'The Antipodes are the dirty bits, the ribald parts which occasionally, unexpectedly speak back. We live in what then Prime Minister [Paul] Keating . . . in the 1990s called the arse-end of the earth. ${ }^{18}$ The concept of the antipodean has been used to study the history of Australia in relation to the United Kingdom, as the term was commonly applied in the late eighteenth and nineteenth centuries to refer to processes of colonisation via the resettlement of convicts from Britain. Indeed, Beilharz also describes how the term was used by Jeremy Bentham in his invention

\footnotetext{
12 Brophy, 1987a.

${ }^{13}$ Brophy, 1987a, p. 20.

${ }^{14}$ Brophy, 1987a, p. 19.

15 Stallard, 2010.

${ }^{16}$ Martin, 1983.

${ }^{17}$ Horne, 1965.

${ }^{18}$ Beilharz, 2005, p. 75.
} 
of the panopticon in the late eighteenth century. As the Antipodes Australia and New Zealand were framed as places for convicts, the exiled, the unwanted, and the term was applied to refer to the 'sewer' or 'effluent' of society. In contemporary art history and cultural studies, the term is used to highlight and theorise what is often said of the culture, art and music of Australia and New Zealand as being 'derivative' or in relation to that of Europe or America. ${ }^{19}$

Antipodean reproduction, when applied theoretically, can be summarised as an elision of a visual distinction between the original and the copy that is bound by a process of negative reversion to the notion of an 'authentic' or concrete original. ${ }^{20}$ The art historian Bernard Smith compiled the original 'Antipodean Manifesto' in 1959, cementing the notion of a trajectory for Australian art history related to its inverse geography and presenting the antipodean as the Other of the 'original' in Europe and the United States. But its theorisation in terms of what Australian art historian Rex Butler has termed to be the effects of mechanical reproduction on Australian art is provided for in Paul Foss' two essays 'Theatrum Nondum Cognitorum' and 'Meridian of Apathy', alongside the essay by Meaghan Morris 'des Epaves/Jetsam'. ${ }^{21}$ Foss and Morris are not responding to Smith's manifesto, which essentially sought to reject abstract art in favour of figurative representation in the context of social realism; rather, they are returning to the construct of the antipodean from Ancient Greece as means to consider the imagistic construct of Australia, and the trajectory of the formation of the south or 'Other world'.

The antipodes confers a "mythical explosion'22 that is radically disconnected from those who have been subsumed by that explosion. Morris calls this a 'topsy-turvy' logic of the antipodes:

From the ancient mapmakers who designed an undiscovered Terra Australia to defy the limits of their world, to more modern pleasantries about the lookingglass land, the Alice country, where all is topsy-turvy and upside-down ('So dry, the bottom's the top'), we find the repetition of a logic requiring an Australia to be there - to balance the earth, to absorb and yet to parody all cultures. For this tradition, an Australian culture would resemble the Black Mass: an inverted reproduction of some original code, serving, perhaps, to guarantee the latter's authenticity while yet acting to contest it. ${ }^{23}$

This theorisation of the antipodean relies upon the concept that Australia was already mapped before it was discovered. Foss reads this from Plato's Timaeus, through to the historical

\footnotetext{
${ }^{19}$ Cf. Smith, 1974; Butler and Donaldson, 2012; Barker and Green, 2010; Clemens, 2011.

${ }^{20}$ As Rex Butler suggests, the antipodean refers to the way in which the artistic visual construct of Australia and its relation to formations of national identity have been 'subject to a particular degree to the effects of mechanical reproduction.' The antipodean confers a form of original unoriginality: 'Australia's identity may well be unoriginal or inauthentic, but this is what is original and authentic about it. Australia might have no identity of its own or its identity might depend on that of other countries, but it embodies this condition more than any of those other countries' (Butler, 2006, p. 17). Body Melt is obviously visibly distinguishable from the classic horror films it draws upon. It is the question of how it targets the spectatorial body that is of interest.

${ }^{21}$ Foss, 1981 and 1982; Morris, 1984.

${ }^{22}$ Morris, 1984, p. 5.

${ }^{23}$ Morris, 1984, p. 6.
} 
search for the antipodes or the south land that marked much of Western culture for centuries until colonisation by Britain in 1788. Foss contends that the actual discovery of Australia was a reproduction of what came before. Representations of Australia are, for Foss, a continuous, material inversion of the past to which it refers. The antipodean perspective is 'the map which precedes the territory; not a "real" Australia that lies at the origin of all its various mappings, but an "infinite regress" of maps which is the secret and enigmatic origin of Australia. ${ }^{24}$ This is its mechanical dimension, and it inscribes how the antipodean representation poses an immanent relation to what it represents. ${ }^{25}$

The question of identity then takes an odd position in an antipodean reading, as Butler suggests: 'if Australia has an identity, it would be found in the fact that it has no identity; that Australia is the difference that makes resemblance possible, the lie that produces truth. ${ }^{26}$ However, while the antipodean is centred 'in relation to everybody else's nuclear other', ${ }^{27}$ Body Melt's antipodean figuration aims at the process of bodily identification with the horror film. Without delving further into Foss's idea, which centres on techniques of mapping and the creation of history, this notion of the absorption as internalisation and subsequent disassociation can be positioned as relative to figuration in Body Melt. As an antipodean reproduction of original sequences, it antagonises the body through an inversion of the rules of the horror film. By badly parodying horror films, it imposes an external awareness of how the horror film exploits the body, an externality that paradoxically comes from within the body of the spectator as they are subjected to bad reproductions of classic sequences. It is useful to recall William Routt's writing on the desiring dimension of the bad movie. Badness, as Routt suggests in his essay 'The Menace', is a kind of recognition of alienation where 'absence is signed by absence, lack by lack . . . the very self I erected the mirror to conceal. A body too little'. ${ }^{28}$ For Routt, an encounter with the bad movie is an encounter with subjectivity. He contends that this is partially to do with the fact that most bad movies are bad because the viewer recognises what is missing or overlooked (such as bad acting, poor lighting, lack of continuity); however he also understands the bad movie as taking delight in that lack: 'Delight entices, ensnares, entraps. I cannot evade delight, once having made the choice to surrender to it. Delight holds, holds me, envaginates me, squeezes me, wrings me out. ${ }^{29}$ Although this is a brief essay, his reading of the bad movie can be framed according to the way in which the spectator seeks out what Brophy has called a loss of control. Rather than a 'profilmic' reality, I argue that bad reproduction in Body Melt locates itself in the physiological response of the spectator.

While I will briefly consider this in terms of Brophy's response to semiotic film theory of the 1970s, in particular in terms of the exclusion of sound in this mode of theory, a return to discuss the film's Australianness allows for further consideration as to the antipodean

\footnotetext{
${ }^{24}$ Butler, 2006, p. 21.

${ }^{25}$ Although I do not address the temporal relation between pre-colonial and settler Australia, the antipodean has been ironically deployed to figure how settler Australia receives and responds to Aboriginal art. See essays by Imants Tillers, Meaghan Morris, and Paul Taylor in the 1982 issue of Art \& Text.

${ }^{26}$ Butler, 2006, p. 20

${ }^{27}$ Foss, 1982, p. 81.

${ }^{28}$ Routt, 1988, p. 75.

${ }^{29}$ Routt, 1988, p. 75.
} 
dimension of the body in Body Melt. Certainly the exaggerated Australian accent forms one element of its antipodean figuration. In the sequence that parodies Alien, shortly after the loss of Cheryl's placenta, her husband Brian returns home to find that his wife is covered in blood and is lying poised with a letter opener above her pregnant stomach. He yells out 'Cheryl!' in an elongated drawl that exaggerates the stereotypical way an Australian accent produces the sound of the name. Before she can stab herself, her foetus forces its way out of her body and smothers Brian's face - another homage to the face-hugging sequence in Alien. Trying to pry himself free of the foetal face-hugger, Brian continues to try to stop Cheryl from taking a knife to her stomach but, in his struggle, he is asphyxiated. Cheryl's stomach tears itself open and she is left dead, her corpse dramatically seizuring on the bed. When read in the context of Body Melt, the inferior or 'bad' Australian accent is one that - like the poor reproduction of the sequence from Alien - is deliberately exaggerated and hyper-materialised such that an ironic opposition to the distinction between viewer and screen is produced. The spectator knows that it is no mistake, in other words, that McCune is called Cheryl; however the effect that is intended to be produced is nonetheless predicated on that of the horror movie. ${ }^{30}$

As well as a filmmaker and film theorist, Brophy is also well known as a sound artist, and the soundscape of Body Melt reflects his experimental and eccentric style. He was the founding member of Melbourne experimental music project $\rightarrow \uparrow \rightarrow$ (pronounced $t$ sk $t$ sk $t$ sk or $t$ ch $t c h$ $t c h$ ) that ran from 1977 until 1986, which also produced a series of Super-8 films and collaborated on his earlier short Salt, Saliva, Sperm and Sweat (a self-described 'philosophy of moisture'). His writing on the topic of sound in cinema includes multiple books, essays, and edited collections. Brophy is particularly polemical and antagonistic in his writing on how the sphere of sound has been addressed in film theory. 'Forget everyone from Kracauer to Bazin to Metz to Mulvey and back again. When scrutinized for their audiovisual nous, the modernist pedagogy of film theoreticians as validated in countless Film studies courses forms a large grey sound-absorbing blanket'. ${ }^{31}$ Brophy considers what he calls the near total lack of attention to sound within traditional paradigms of Film Theory, and the likeminded tendency to place sound as a mere 'added' or 'extraneous' component mutes the film. While discussion of a theory of sound would be useful here, I want to focus on such motifs as forms of antipodean reproduction in order to further understand and theorise the antagonistic dimension of this film as it relates to the body (rather than specifically to the senses). Brophy's address to sound is certainly in his tradition of antagonism. Semiotic film theorists of the 1970s and 1980s, in particular Christian Metz and Jean Louis Baudry, argued that cinema instituted an all-encompassing visual fantasy such that the spectator's body, or sense of self, was rendered internally or 'subjectively' invisible by way of a totalising visual continuum between spectator and screen. ${ }^{32}$ In other words, cinema's aesthetic caused the spectator to be alienated from their bodily subjectivity by the effect of the apparatus. Without specifically addressing this mode of theory, which has already been widely critiqued, I do not doubt that, to a certain extent, the antagonising elements of Body Melt is also a response to

\footnotetext{
${ }^{30}$ Other noteworthy Cheryl's of Australian culture of similar vernacular are 'Feral Cheryl' the anti-Barbie doll, Cheryl from Muriel's Wedding, 1994, Cheryl from Puberty Blues, 1981, and Cheryl from The FJ Holden, 1977. For discussion of the Australian accent, see Coyle, 2000.

${ }^{31}$ Brophy, 1999, p. 110.

${ }^{32}$ Metz, 1982; Baudry, 1986.
} 
the ubiquity of this theory at the time.

I have argued in this essay that the affective response to Body Melt is predicated on its bad reproduction of scenes in horror films already known to the spectator. I have understood this through the figure of the antipodean, and suggested that the antagonism of Body Melt can be understood as illuminating the process of identification with the horror film. Its bad copying of scenes from championed horror films is not merely deliberate, but a direct exploitation of Brophy's theory for the manner in which the viewer's body responds to the horror film in an irrational (but nonetheless deliberate) sense. Therefore, I want to conclude with Ozploitation cinema (Australian exploitation film), as Body Melt can be positioned as at the end of the golden-age of this period in Australian cinema so it also provides an antipodean perspective on this particular form, the exploitation film.

Body Melt was more-or-less excluded from the 2008 documentary on Australian exploitation cinema directed by Mark Hartley Not Quite Hollywood: The Wild, Untold Story of Ozploitation. Despite his profuse contribution to Australian cinema and criticism, both Brophy and his work only received a very brief mention. Australian exploitation films have only recently been labelled as 'Ozploitation'. 33 Australian Exploitation Cinema or 'Ozploitation' probably has its beginning in the work of the now famous Hollywood filmmakers George Miller (director of Mad Max) and Peter Weir (best known in a mainstream Australian context as director of Picnic at Hanging Rock). Miller's first short is Violence in the Cinema: Part 1, where a psychologist is brutally attacked and murdered as he attempts to explain the effects of violent films on the spectator. Weir's early career is marked with two provocative films, the short Homesdale, in which guests at a homestead are invited by their hosts to act out their violent fantasies, and the feature The Cars that Ate Paris, in which the residents of 'Paris', a small outback town, are devoured by possessed cars. Indeed, as a genre, Australian exploitation cinema continues well into the late 1980s and early 1990s.

What marks Australian exploitation cinema is that it is repeatedly valued as being overlooked or 'untold'. While the documentary - despite its exclusion of Brophy - otherwise provides a thorough overview of its history, it notably includes Quentin Tarantino as the 'champion' of the genre, and the title of the documentary, which considers Ozploitation the untold or forgotten story, is revealing in both the context of exploitation cinema and in consideration of its antipodean origins.

Adrian Martin has called the rise of 'Ozploitation' a retrospective revisionism of Australian film history:

Ultimately, Not Quite Hollywood itself plays a policing, repressive role in film-cultural matters: through its unspoken and unargued principles of selection, it tacitly presumes to divide (as any polemic would, and does) authentic 'maverick genre entertainments for the masses' from every other

\footnotetext{
${ }^{33}$ Martin, 2010; Thomas, 2009.
} 
kind of experiment with generic styles and modes of address. Our view of Australian film history is immediately both richer and poorer for it. ${ }^{34}$

His critical position is pointed at the title and the contradiction that it hinges on: 'On the one hand it can mean, cheekily, "nothing at all like Hollywood", i.e., a radical alternative to the mainstream. But, on the other hand, it means "almost like Hollywood", i.e., almost getting to the mainstream and the success to be won there, if only it could receive the recognition, acclaim and financial hand-up it needs. ${ }^{35}$ Certainly, the inclusion of Tarantino to 'legitimise' the genre is indicative of this, and I would agree with Martin that there is a need to attend to the fact that these are exploitation films.

We can return to Brophy's own study of the value of Australian exploitation films from the 1980s, as he described them as 'not part of a continuum of any sort' but rather as 'historical oddities, flukes or one-shots. ${ }^{36}$ While like many he called for more exploitation films to be made and distributed, he still emphasised that the value of Australian exploitation cinema is that it actively and deliberately opted to sit outside any possible continuum. Of relevance are two of Brophy's essays from the late 1980s, 'That's Exploitation Part 1 and 2:

Snobs/Turkeys', ${ }^{37}$ and their reflection on Trenchard-Smith's 1982 exploitation film Turkey Shoot (produced by Antony I. Ginnane also famous for Thirst and Patrick). In these essays, Brophy polemically rejects the near totality of Australian film production to date, calling everything a form of cultural 'advertising': '[T]he carcass of Kangaroo is just as rotten as the dead bodies in Gallipoli. ${ }^{38}$ In his polemical address, Brophy pushes for exploitation cinema that is opposed to all forms of value, sense or taste through his reading of Turkey Shoot (also titled Escape 2000, and Blood Camp Thatcher). This is a post-apocalyptic dystopian film set in the 'near future' in which three rebel inmates at a re-education camp are bargained in a deal. In order to be set free, the prisoners must take part in a 'turkey shoot' - officers will hunt the inmates down in the nearby jungle, and if they can escape then everyone will be set free. As Brophy explains, Turkey Shoot is a political satire where any 'legitimate' political commentary is undone by its value as an exploitation film. He writes:

Its production states: national identity belongs to the highest bidder. . . . The commercial success of a film is not really at stake here either, for (a) Ginanne and Trenchard-Smith surely would have died of heart attacks if the film came in as a block-buster, and (b) its life span on our theatrical circuit is - by virtue of its exploitative nature - strategically designed to disappear as much as it appears, meaning that it has to flash across the country in order to realise its profit potential. .. . That's exploitation - keep your finger on a pulse only to

\footnotetext{
${ }^{34}$ Martin, 2010, p. 15.

${ }^{35}$ Martin, 2010, p. 15.

${ }^{36}$ Brophy, 1987b, p. 29.

${ }^{37}$ Brophy, 1987b; Brophy, 1987c.

${ }^{38}$ Brophy, 1987b, p. 29.
} 
lift it off as quickly as you laid it on ... That's development - real cultural development: messy, ad hoc, aleatory, random. ${ }^{39}$

The hybridity and inversion of values that a film like Turkey Shoot represents — insofar as it is an inverted political critique of political activism — are also present in Body Melt as it attempts to be unwatchable by being dismissive and outrageous toward the game of the horror movies, draining their original, and cultural, inflection as it toys with the expectation of horror. Like Turkey Shoot, Body Melt is deliberately bad, a badness that can be thought through the intersection between the body and the screen. Figuration in Body Melt is antipodean as it works to simultaneously devour and further alienate the original scenes of horror that aim at bodily affect. The final echo of this perverse, but humorous, playing is that it badly copies scenes of horror without regret.

Lauren Bliss is a writer-researcher based in Melbourne, she recently completed a PhD in screen studies at the University of Melbourne.

\section{Bibliography}

Barker and Green, 2010: Charles Barker and Heather Green, 'No More Provincialism: Art \& Text', Emaj, 5, 2010, pp. 1-30.

Baudry, 1986: Jean Louis Baudry 'Ideological Effects of the Basic Cinematographic Apparatus' and, 'The Apparatus: Metapsychological Approaches to the Impression of Reality in the Cinema,' in Narrative, Apparatus, Ideology: A Film Reader, ed. Philip Rosen, New York: Columbia University Press, 1986, pp. 286 - 318.

Beilharz, 2005: Peter Beilharz, 'Australia: The Unhappy Country, or, a tale of two nations', Thesis 11, 82, no. 1, 2005, pp. 73-87.

Brophy, 1983: Philip Brophy (ed.), Made by $\rightarrow \uparrow \rightarrow 1977-1982$, Northcote: Tch Tch Tch Publications, 1983.

Brophy, 1984: Philip Brophy, 'Tales of Terror', Cinema Papers, no. 49, December, 1984, pp. 400-7.

Brophy, 1986: Philip Brophy, 'Horrality', Screen, 27, nos. 1-2, 1986, pp. 2-13. Originally published in Art \& Text, 11, Spring, 1983, pp. 85-95.

Brophy, 1987a: Philip Brophy, 'This isn't a film: it's a disease', Cinema Papers, no. 62, March, 1987, pp. 18-22.

\footnotetext{
${ }^{39}$ Brophy, 1987c, p. 42.
} 
Brophy, 1987b: Philip Brophy, 'That's Exploitation: Snobs', Filmviews, no. 132, 1987, p. 29.

Brophy, 1987c: Philip Brophy, 'That's Exploitation: Turkeys', Filmviews, no. 133, 1987, pp. 41-42.

Brophy, 1992: Philip Brophy, 'Read My Lips: Notes on the Writing and Speaking of Film Dialogue', Continuum, 5, no. 2, 1992, pp. 247-66.

Brophy, 1999: Philip Brophy, 'Being Blind: A Polemical Manual for Using New Audiovisual Technologies', Iris, no. 27, 1999, pp. 110-118.

Brophy, 2006: 'Interview with Philip Brophy', (by the Kingpins) Photofile, no. 77, 2006, pp. 18-23.

Butler, 2004: Rex Butler, 'Introduction', in Rex Butler (ed), What Is Appropriation: An Anthology of Critical Writing on Australian Art in the '80s and '90s, Brisbane and Sydney: IMA and Power Publications, 2004, pp. 13-46.

Butler and Donaldson, 2012: Rex Butler \& ADS Donaldson, 'Against Provincialism: Australian-American Connections 1900-2000', Journal of Australian Studies, 36, no. 3 , 2012, pp. 291-307.

Clemens, 2011: Justin Clemens, Minimal Domination, Melbourne: Surpllus, 2011.

Cholodenko, 2010: Alan Cholodenko, 'The ABC's of B, Or: To B or not To B', Film Philosophy, 14, no. 2, 2010, pp. 84-112.

Coyle, 2000: Rebecca Coyle, 'Speaking Strine: Locating 'Australia' in film dialogue', in Philip Brophy (ed), Cinesonic: experiencing the soundtrack, Sydney: Australian Film, Television and Radio School, 2000, pp. 203-224.

Foss, 1981: Paul Foss, 'Theatrum Nondum Cognitorum', in Peter Botsman, Chris Burns and Peter Hutchings (eds), The Foreign Bodies Papers, Sydney: Local Consumption Publications, 1981: pp. 15-38.

Foss 1982: Paul Foss, 'Meridian of Apathy,' Art \& Text, no. 6, 1982, pp. 74-89.

Frow, 1995: John Frow, Cultural Studies and Cultural Value, Oxford: Clarendon, 1995.

Frow, 2006: John Frow, Genre: The New Critical Idiom, London and New York: Routledge, 2006. 
Frow and Morris, 1993: John Frow and Meaghan Morris, 'Introduction', in John Frow and Meaghan Morris (eds), Australian Cultural Studies: A Reader, Sydney: Allen and Unwin, 1993, pp. vii-xxxii.

Horne, 1965: Donald Horne, The Lucky Country, 2008 ed., Camberwell: Penguin, 1965.

Martin, 1983: Adrian Martin, 'Foreign Intrigue, Culture and Nationalism,' Island, no. 16, September 1983, pp. 21-24.

Martin, 2001: Adrian Martin, 'Body Melt' sourced from the author, originally published in Senses of Cinema, no. 16, September-October, 2001.

Martin, 2010: Adrian Martin, 'Ozploitation Compared to What? A Challenge to Contemporary Australian Film Studies', Studies in Australasian Cinema, 4, no. 1, 2010, pp. 9-21.

Metz, 1982: Christian Metz, The Imaginary Signifier: Psychoanalysis and the Cinema, trans. Celia Britton et al., London: Macmillan, 1982.

Morris, 1984: Meaghan Morris, 'des Epaves/Jetsam', On the Beach, nos. 3-4, 1984, pp. 2-6.

Routt, 1988: Bill Routt, 'The Menace', SubStance, 17, no. 1, issue 55, 1988, pp. 69-76.

Smith, 1974: Terry Smith, 'The Provincialism Problem,' Artforum, XIII, no. 1, September, 1974, pp. 54-9.

Smith, 1975: Bernard Smith, The Antipodean Manifesto: Essays in Art History, Melbourne: Oxford University Press, 1975.

Stallard, 2010: Avan Stallard 'Origins of the Idea of the Antipodes: Errors, Assumptions and a Bare Few Facts’, Terrae Incognitae, 42, no. 1, 2010, pp. 34-51.

Thomas, 2009: Deborah Thomas, 'Tarantino's Two Thumbs Up: Ozploitation and the Reframing of the Aussie Genre Film', Metro Magazine, no. 161, 2009, pp. 90-95.

\section{Illustrations}

Fig. 1. Screenshot from Body Melt: Cheryl (Lisa McCune) hunting down her lost placenta. (Copyright: Philip Brophy.)

Fig. 2. Screenshot from Body Melt: Cheryl after the foetus has burst out from her uterus. (Copyright: Philip Brophy.) 